\title{
Screening for cervical cancer: New alternatives and research
}

\author{
Attila T Lörincz, PhD.(1)
}

\section{Lörincz AT. \\ Screening for cervical cancer: New alternatives and research. Salud Publica Mex 2003;45 suppl 3:S376-S387. This paper is available too at: http://www.insp.mx/salud/index.html}

\begin{abstract}
A bstract
Evidence for the clinical utility of human papillomavirus (HPV) DN A testing has increased over the years and has now become very convincing. Some specific uses of HPV detection are a) triage of women with cytological determinations of atypical squamous cells of undetermined significance (ASC-US) and related management strategies, $b$ ) as a marker for test of cure post-treatment, and c) most importantly, as an adjunct to cytology in routine cervical disease screening programs. There are many studies that support each of these applications and include 8 studies on ASC-US triage, 10 on test of cure and 13 on adjunctive or stand-alone H PV screening.The most notable investigation of ASC-US triage was ALTS, a randomized controlled trial of 3488 women.W ith respect to routine HPV screening the combined studies included 77000 women, providing as a histological endpoint more than 1000 cases of high-grade cervical intraepithelial neoplasia (C IN) or cancer. Testing methods were either the Hybrid Capture 2 (HC2) test or the polymerase chain reaction (PCR) test. HPV testing of women with ASC-US cytology had on average a higher sensitivity (90\%) and specificity (70\%) than repeating the cytological test (sensitivity $75 \%$, specificity $60 \%$ ) and was also more sensitive than colposcopy for follow-up.As an adjunct to the Papanicolaou (Pap) cytology test in routine screening, H PV DN A testing was a more sensitive indicator for prevalent highgrade CIN than either conventional or liquid cytology. A combination of HPV DN A and Papanicolaou testing had almost $100 \%$ sensitivity and negative predictive value. The specificity of the combined tests was slightly lower than the specificity of the Papanicolaou test. O ne "double-negative" HPV DN A and Papanicolaou test indicated a higher prognostic assurance against risk of future CIN 3 than three subsequent negative conventional Papanicolaou tests and may safely allow threeyear or longer screening intervals for such low- risk women.
\end{abstract}

Lörincz AT.

Detección oportuna de cáncer cervical: nuevas alternativas y pautas de investigación.

Salud Publica Mex 2003;45 supl 3:S376-S387.

Este artículo también está disponible en:

http://www.insp.mx/salud/index.html

\section{Resumen}

Evidencia de la utilidad clínica de la determinación de ADN del virus del papiloma humano se ha incrementado durante los últimos años,y ahora ha llegado a ser convincente. Algunos de los usos específicos de la prueba de este virus son: a) vigilancia de mujeres con diagnóstico de atipia de células escamosas de significancia no determinada (ASC-US) y las relacionadas con su estrategia de manejo, b) como un marcador de curación postratamiento, y c) más importante, como una prueba adicional a la citología en la rutina de programas poblacionales de detección oportuna de cáncer cervical. Existen muchos estudios que son el referente de estas afirmaciones, entre los que se encuentran ocho sobre la vigilancia de ASC-US, 10 que estudiaron curación, y 13 que han evaluado su utilidad en programas de detección poblacional. La más notable investigación sobre ASC -US es conocida como ALTS, un ensayo controlado aleatorizado de 3488 mujeres. Respecto a la rutina del virus del papiloma humano (VHP) como estrategia de tamizaje, los estudios combinados se hicieron en 77000 mujeres y dieron como resultado el diagnóstico histológico de más de 1000 casos de lesiones de alto grado de neoplasia intraepitelial cervical 0 cáncer. Los métodos utilizados para determinar este virus han sido captura de híbridos de segunda generación (HC2) 0 la prueba de reacción de polimerasa en cadena (PCR). La prueba del VPH por HC2 en mujeres con diagnóstico citológico de ASC-US HPV han tenido en promedio una muy elevada sensibilidad $(90 \%)$ y especificidad $(70 \%)$, en comparación con la prueba repetida de citología (sensibilidad $75 \%$, especificidad $60 \%$ ); y son más sensibles que la colposcopía para seguimiento. Como una prueba adyuvante al Papanicolaou, la rutina de tamizaje con el VPH ha sido un indicador más sensible para identificar lesiones prevalentes de neoplasia intraepitelial cervical de alto grado que la prueba convencional

(1) Digene Corporation, Gaithersburg, Maryland, USA.

Received on: A pril 8, 2003 - Accepted on: A pril 10, 2003

Address reprint requests to:Attila T Lörincz, PhD. Digene Corporation. 1201 Clopper Road, Gaithersburg, MD 20878, USA.

E-mail: attila.lorincz@ digene.com 
It appears that HPV DN A testing is on the way to becoming a common testing strategy in cervical cancer prevention programs. Research continues into approaches for improving the performance and cost-effectiveness of HPV detection methods. Hybrid Capture 3 will offer improved HPV typing capabilities and the Rapid Capture machine allows for robotassisted H PV D N A testing, permitting greater test throughput. PCR test improvements are expected to contribute to the grow th of flexible accurate and cost-effective HPV DN A tests. It is likely that improved diagnostic technology along with HPV genotyping and quantitation may provide more value in future. A particularly promising approach is to combine HPV DNA testing with expression levels of other markers such as proliferative or cell cycle regulatory proteins to subdivide HPVpositive women into those who are at greater risk of cancer and those who can be safely followed by screening at longer intervals.This paper is available too at:http://www.insp.mx/salud/ index.html

Key words: cervical cancer, screening, human papillomavirus, Papanicolao u, Mexico de Papanicolaou o de citología líquida. Una combinación del VPH y citología cervical tiene casi $100 \%$ de sensibilidad y valor predictivo negativo. La especificidad de las pruebas combinadas ha tenido sólo una menor especificidad que la o bservada en citología. Una prueba "do ble negativa" delVPH y citología brinda a la mujer un mejor pronóstico en contra del riesgo de desarrollar neoplasia cervical, en comparación con tres pruebas consecutivas de Papanicolaou, y puede brindar seguridad de un nuevo tamizaje en un intervalo de tres años para mujeres de bajo riesgo. Las pruebas para el virus del papiloma humano posiblemente se constituyan en la estrategia más común de tamizaje en programas poblacionales de detección oportuna de cáncer. La investigación continúa para mejorar la sensibilidad y costo-efectividad de métodos de detección de este virus. La captura de híbridos de tercera generación puede brindar la posibilidad de mejorar la tipificación del virus con máquinas de captura rápida mediante robots para asistir la determinación del virus, permitiendo el tamizaje masivo. La implantación de pruebas de PCR son esperadas para contribuir en el mejoramiento de pruebas más costo-efectivas y flexibles. Es factible que el mejoramiento en la tecnología diganóstica en la genotipificación y cuantificación del virus del papiloma humano puedan proveer mayor valor en el futuro. Una posibilidad promisoria es la combinación de pruebas de este virus con niveles de expresión de otros marcadores como células proliferativas o proteínas del ciclo regulator io que subdividen mujeres positivas a este virus en aquellas que tienen el más alto riesgo de cáncer y aquellas que, en forma segura, pueden ser tamizadas a más largos intervalos. Este artículo también está disponible en: http://www.insp.mx/salud/index.html

Palabras clave: cáncer cervical; detección oportuna de cáncer; virus de papiloma humano; México
C ervical and other anogenital cancers with an HPVrelated etiology are among the most important cancers of women worldwide. The estimated global incidence of cervical cancer is estimated 470600 cases per year with approximately 233400 deaths. ${ }^{1}$ Mexico is one of the hotspots for cervical cancer with an incidence of the disease in many parts of the country of more than 40 per 100000 women, which unfortunately has been slowly increasing over the years. ${ }^{2}$ In contrast, in the United States of America (USA) and many European countries the incidence of cervical cancer is quite low, typically on the order of 5 to 15 cases per 100000 women, with overall associated mortality of less than $25 \%$. The reasons for these disparities in cancer incidence are manifold but depend most heavily on the existence and relative effectiveness of mass screening programs to detect and eradicate premalignant disease before it becomes malignant and difficult or impossible to treat. Prior to the introduction of screening cytology the incidence of cervical cancer in the USA and Europe was quite similar to that of developing countries today. It was the invention of the cervical cytology test by Dr Papanicolaou ${ }^{3}$ that led to the dramatic drop in cervical cancer rates. The Pap test has been heralded as one of the more important advances in medical science in the $20^{\text {th }}$ century. However, despite the success of cytologybased screening programs, the true sensitivity of the conventional Pap test is on the order of 50 to $60 \%$ in the routine screening setting. ${ }^{4-6}$ The impressive reduction in cervical cancer incidence is the result of carefully orchestrated Pap test programs involving repetition of the test every year or every few years in women with a history of normal Pap results. And therein lie some of the weaknesses of the Pap test, including the need for frequent repetition of the test, which raises costs considerably and results in excessive interventions secondary to the increase in false-positive rates. Another question relates to prevention effectiveness as many women still develop cervical cancer despite the presence of extensive screening programs. In the USA for example 
approximately 4000 women per year are diagnosed with cervical cancer despite fairly routine attendance for cytological screening. It is increasingly regarded as better practice to administer a more sensitive test or test combination less frequently than to administer a less sensitive test more frequently. The exact decisions of implementation and frequency of repetitions should be based on cost-effectiveness studies.

The current interest in HPV stems from the fact that a specific group of types, referred to as the carcinogenic HPVs, are causally involved in the development of certain human cancers, most notably cervical cancer.? Over $95 \%$ of cervical cancers have HPV DNA detectable by sensitive methods such as Hybrid Capture 2 (HC2) and polymerase chain reaction (PCR). ${ }^{8-12}$ The rationale for the use of adjunctive HPV DNA testing in screening applications is based on the increasingly accepted concept of necessary causality and on the basis of the very high negative predictive value (NPV) of the combined HPV DNA plus Papanicolaou tests, typically $99.9 \%$ to $100 \%$.

\section{Material and Methods}

The HC2 test is a standardized US FDA-approved test that has been employed extensively in research studies and has been in routine clinical use for more than three years. $\mathrm{HC} 2^{13}$ can detect one or more of 13 carcinogenic HPV types $(16,18,31,33,35,39,45,51,52,56,58,59$ and 68 ) at the level of $1 \mathrm{pg} / \mathrm{ml}$ each, which corresponds to $5900 \mathrm{HPV}$ genomes per test well. There are no FDAapproved PCR tests for HPV DNA and the studies described herein all employed well-validated research PCR methods.

Specimens for HPV testing in the reviewed studies were collected from the transformation zone by several different techniques. Most commonly a small conical brush was employed (Digene Cervical Sampler ${ }^{\mathrm{TM}}$ cervical brush, Digene Corporation, Gaithersburg, Md USA) that was rotated three times in the cervical os and then placed into a $1 \mathrm{ml}$ tube of transport medium. Some studies, however, used a standard plastic spatula and cytobrush combination $^{14}$ (Cooper Instruments, Hollywood, Fla USA) or a broom device ${ }^{15}$ (Cervex-Brush ${ }^{\circledR}$, Unimar, Wilton, Conn USA) to collect specimens for deposition into $20 \mathrm{ml}$ of PreservCyt ${ }^{\circledR}$ (Cytyc Corporation, Boxborough, Mass USA) liquid cytology medium. In the study by Kjaer et al, ${ }^{16}$ PCR testing was performed on specimens collected into phosphate-buffered saline. It is notable that HPV DNA testing in the Portland study, started in 1989, was conducted on cervicovaginal lavage specimens, a technique that is inadequate for sampling the endocervical canal. This specimen limitation is likely accentuated in older women who have a higher frequency of receding transformation zone and stenotic $0 s^{17,18}$ and thus may have compromised the HPV DNA test data.

This review focuses on the larger ASC-US studies and adjunctive screening studies of 1000 or more women that employed HC2 or PCR in a manner that allowed reliable estimates of accuracy for detecting high-grade CIN or cancer. Unfortunately data for use of HPV DNA detection as a marker for test of cure are available only from small groups of women. Studies that employed poorly characterized populations of women or had more than a minor proportion of special groups such as STD or hospital clinics were excluded unless convincing evidence was supplied that these groups were representative of the larger screening population in the general locale of the study. Studies were required to have a well-described high-grade cervical disease reference standard rendered by expert pathologists or panels of reviewers. Histological grading was categorized as either CIN $2 / 3$ or CIN 3. Any cancers in the studies were included in the CIN groups because the cancers were less than $10 \%$ of the total numbers of high-grade intraepithelial lesions and results were unaffected by the presence or absence of the cancers (data not shown). Statistical methods are described below as appropriate with additional details given in the original publications. $95 \%$ confidence intervals calculated for this review are binomial exact values from StatXact 5.0 (Cytel, Cambridge, Mass USA). For some studies such as ALTS, 95\% CI data for test sensitivities are as reported and for missing values such as specificities are exact binomials calculated by StatXact 5.0 on best estimates of the underlying counts as determined by Bayes methods.

\section{HPV DNA testing for ASC-US triage and related uses}

The first formally validated use for HPV DNA testing was ASC-US triage. Numerous studies have been conducted employing various HPV detection methodologies to understand this application thoroughly. Figure 1 and Table I show data from the more notable AS-CUS triage studies selected on the somewhat arbitrary basis of having at least 15 cases of CIN 2/3 and a uniform HPV DNA testing approach (the HC2 HPV DNA test). Figure 1 shows a receiver operator characteristic (ROC) analysis of the summary data. The most important study in this category was the ASCUS LSIL Triage Study (ALTS), which was the only randomized controlled trial and included 3488 women, with the first round of baseline visits yielding 323 cases of CIN 2/3 for all three study arms combined (Table I) 


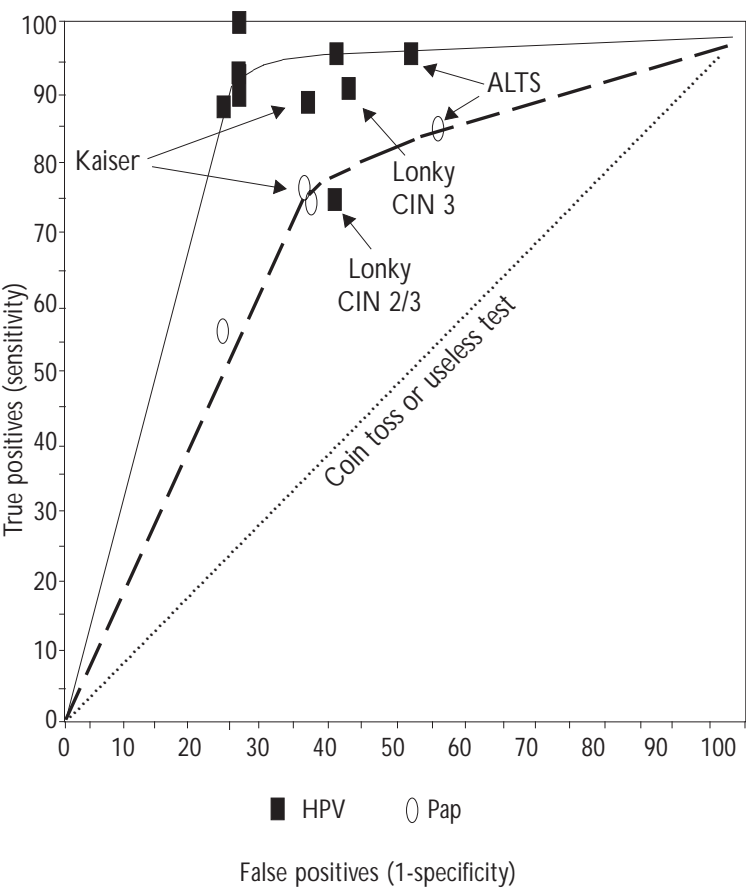

Figure 1. Receiver operator characteristic CURVES fOR HPV DNA AND PAP TESTS IN EIGHT ASC-US tRIAGE STUDIES.THEALTS, ${ }^{15} \mathrm{KAISER}^{21}{ }^{21}$ AND LONKY ${ }^{22}$ STUDIES ARE INDICATED BY ARROWS BECAUSE THESE ARE OF SPECIAL INTEREST AS DESCRIBED IN THE RESULTS

Table I

Number OF WOMEN AND CASES OF FINAL HISTOLOGICALLY DEFINED, HIGH-GRADE CERVICAL DISEASE IN SELECTED ASC-US TRIAGE STUDIES THAT EMPLOYED HC2 HPV DNA TESTING

\begin{tabular}{lcc} 
Study & Women & CIN2/3 or CIN3+* \\
Manos $1999^{40}$ & N & \\
\hline Lin 200041 & 995 & 65 \\
\hline Shlay 200042 & 74 & 27 \\
\hline Zielinski 200143 & 195 & 15 \\
\hline Morin 2001 & 278 & 27 \\
\hline Solomon 20014 & 360 & 19 \\
\hline Pretorius 2002 & 3488 & 323 \\
\hline Lonky 200322 & 845 & 50 \\
* The histological endpoint for the studies varied and was either CIN 2/ \\
3 or C IN 3. Except for the Lonky study the inclusion of C IN 2 with the \\
CIN 3 did not alter the main results
\end{tabular}

and a final yield of 533 cases of CIN 2/3 over the two year follow-up interval. ${ }^{19}$ Detailed baseline data for ALTS has been published by Solomon and Schiffman et $a l$, and others. ${ }^{15,20}$ The next most important study was conducted at Kaiser Permanente in California by Manos et al. ${ }^{21}$ The Kaiser study preceded ALTS and examined over 900 women with ASC-US, of whom 64 were shown to have CIN 2/3 (Table I). All eight studies were consistent and demonstrated that HPV DNA testing is highly sensitive and specific for detecting CIN 2/3 or CIN 3 (Figure 1). In ALTS the sensitivity and specificity of the HPV DNA testing strategy estimated after the baseline clinical visits and workup was reported as $96.3 \%(95 \% \mathrm{CI}=91.6-98.8 \%)$ and $49 \%(95 \% \mathrm{CI}=47.3-$ $50.8 \%$ ). In contrast the sensitivity and specificity of repeat ThinPrep liquid cytology was reported as $85.3 \%$ (95\% CI $=78.2-90.8 \%$ ) and $45 \%$ (95\% CI $=43.4-46.8 \%)$. Repeat Pap test data were presented for only four of the studies but from these it is possible to determine that the HPV DNA test was not only more sensitive than the Pap test but was also more specific, as can be deduced from the superior HPV DNA curve in Figure 1. There was an unusual exception in the recent small study of Lonky et al ${ }^{22}$ where the sensitivity for CIN 2/3 was worse than for CIN 3 alone; in fact for CIN 2/3 the HPV sensitivity was close to the Pap ROC curve. In contrast, in the other studies for which data were available, the sensitivity and specificity of the HPV test for CIN 2/3 and for CIN 3 were similar. The basis for the inconsistency in the Lonky study is currently unclear but could be related to overcall of CIN 1 and grouping of some of these lesions with the high-grade category. Longitudinal data from ALTS has revealed that HPV DNA testing is not only more sensitive than the ThinPrep liquid cytology test but is also more sensitive than colposcopy. ${ }^{19}$ Summary data showing test performance observations for two years of follow-up, are presented in Figure 2.

\section{HPV DNA testing as a marker for test of cure}

The rationale behind the proposal to use HPV DNA testing to determine the risk of residual or recurrent CIN $2 / 3$ post-treatment is based on the understanding that without detectable HPV DNA there is a very low probability of the existence of true CIN 2/3. This expectation has been essentially confirmed by the ten studies presented in Table II. Although the studies were each quite small and employed a diversity of designs and testing methodologies the consistency of the data from these different research groups in several countries support test of cure as a valid clinical use for HPV DNA testing. Combining the relevant data from the studies 


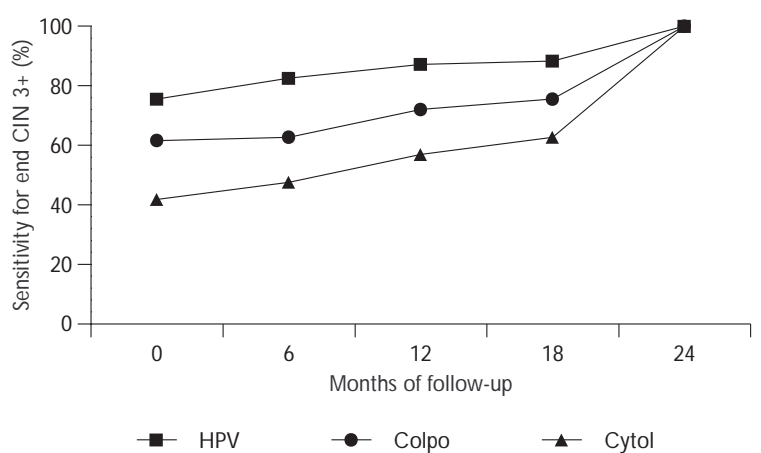

Figure 2. Detection of high-grade cervical disease IN THE HPV, COLPOSCOPY, AND CYTOLOGY ARMS OF THE ALTS TRIAL OVER THE FOLLOW-UP PERIOD.ADAPTED FROM The ASC-US-LSIL Triage Study (ALTS) Group $2003^{19}$

Table II

HPV DNA Detection as a test of CURE. Results OF 10 STUdies deMONSTRATING THAT LACK OF HPV DNA DETECTABILITY CORRELATES WITH LOWER RISK OF RESIDUAL OR RECURRENT CIN 2/3.THE HPV DATA ARE LINKED TO THE CIN 2/3 DATA TO THE IMMEDIATE RIGHT.THUS, FOR HPV TEST POSITIVE WOMEN INDICATED AS HPV (+) POST TREATMENT, THE COLUMN

TO THE IMMEDIATE RIGHT INDICATES THE NUMBER OF CASES OF CIN 2/3 DETECTED AMONG THESE WOMEN IN EACH STUDY.THE HPV (-) DATA ARE INTERPRETED ACCORDINGLY

\begin{tabular}{|c|c|c|c|c|c|}
\hline \multirow[b]{2}{*}{ Study } & \multirow{2}{*}{$\begin{array}{c}\text { Women } \\
\mathrm{N}\end{array}$} & \multicolumn{4}{|c|}{ Post-treatment results } \\
\hline & & $\overline{\mathrm{HPV}}(+)$ & $\operatorname{CIN} 2 / 3$ & HPV(-) & CIN2/3 \\
\hline Elfgren $1996^{46}$ & 23 & 4 & 4 & 19 & 0 \\
\hline Bollen $1997^{47}$ & 91 & 30 & 5 & 61 & 0 \\
\hline Chua $1997^{24}$ & 48 & 24 & 24 & 24 & 2 \\
\hline $\mathrm{N}$ agai $2000^{48}$ & 58 & 11 & 5 & 47 & 0 \\
\hline Kjellberg $2000^{49}$ & 75 & 2 & 0 & 73 & 0 \\
\hline Paraskevaidis $2001^{23}$ & 123 & 51 & 38 & 72 & 3 \\
\hline Lin $2001^{50}$ & 75 & 52 & 27 & 23 & 0 \\
\hline Jain $2001^{51}$ & 111 & 76 & 32 & 35 & 0 \\
\hline Elfgren $2002^{52}$ & 45 & 2 & 1 & 43 & 0 \\
\hline Bodner $2002^{53}$ & 37 & 10 & 3 & 27 & 0 \\
\hline
\end{tabular}

there were 686 women followed post-treatment from whom $144(21 \%, 95 \% \mathrm{CI}=18-24.2 \%)$ cases of histologically diagnosed residual or recurrent CIN 2/3 were discovered over the following year. There were 262 $(38.2 \%, 95 \% \mathrm{CI}=34.5-42 \%)$ women in the combined group who had a positive HPV test for a carcinogenic
HPV type during follow-up and 139 of the 144 cases of CIN 2/3 detected were among these HPV- positive women. Thus, the overall sensitivity, specificity, positive predictive value (PPV), and negative predictive value (NPV) of HPV testing for CIN 2/3 post-treatment is estimated as $96.5 \%$ (95\% CI $=92.1-98.9 \%), 77.3 \%(95 \%$ $\mathrm{CI}=73.5-80.8 \%), 53 \%(95 \% \mathrm{CI}=46.8-59.2 \%)$, and $98.8 \%$ $(95 \% \mathrm{CI}=97.3-99.6 \%)$, respectively. Most of these studies did not give comparable performance data for repeat Pap smear testing but it is generally known that repeat cytology is insensitive for residual disease and followup strategies post-treatment usually also include at least one repeat colposcopy at 4 to 6 months.

In some papers performance data for the Pap test were provided. For example, Paraskevaidis et al, ${ }^{23}$ in one of the larger studies of 123 women, presented data from which the sensitivity of the repeat Pap test was estimated as $48.8 \%(95 \% \mathrm{CI}=32.9-64.9 \%)$ and of HPV testing as $92.7 \%(95 \% \mathrm{CI}=80-98.5 \%)$. In some papers the specificity of the Pap test was $86.6 \%$ (95\% CI = 77.3-93.1\%), and of $\mathrm{HPV}$ it was $84.1 \%$ (95\% CI $=74.4-91.3 \%)$. PPV and NPV for the Pap test were $64.5 \%(95 \% \mathrm{CI}=45.4-80.8 \%)$ and $77.2 \%$ (95\% CI $=67.2-85.3 \%$ ) respectively, while for HPV DNA testing PPV and NPV were 74.5\% (95\% CI $=60.4$ $85.7 \%)$ and $95.8 \%(95 \% \mathrm{CI}=88.3-99.1 \%)$ respectively. In a smaller study of only 48 women, Chua ${ }^{24}$ reported data from which the sensitivity, specificity, PPV and NPV of the Pap test were estimated as 50\% $(95 \% \mathrm{CI}=29.9-70.1 \%)$, $90.9 \%(95 \% \mathrm{CI}=70.8-98.9 \%), 86.7 \%(95 \% \mathrm{CI}=59.5-98.3 \%)$, and $60.6 \%(95 \% \mathrm{CI}=42.1-77.1 \%)$ respectively, while the sensitivity, specificity, PPV, and NPV of the HPV DNA test were estimated as $92.3 \%$ (95\% CI $=74.9-99 \%), 100 \%$ $(95 \% \mathrm{CI}=84.6-100 \%), 100(95 \% \mathrm{CI}=85.8-100 \%)$ and $91.7 \%$ $(95 \% \mathrm{CI}=73-99 \%)$ respectively.

\section{HPV DNA testing for adjunctive screening with cytology or as a stand-alone test}

Numerous large HPV screening studies have been published that have spanned a broad range of geographic, ethnic, and socioeconomic groupings, representing many of the major populations worldwide. The studies considered here varied widely from 1365 women in Cape Town South Africa ${ }^{25}$ to 20810 women in Portland Oregon. ${ }^{18}$ Overall, the studies included more than 77000 women and more than 1000 cases of CIN $2 / 3$ spanning four continents and 11 countries. There was little difference in the performance of the tests whether histologically diagnosed CIN $2 / 3$ or $\mathrm{CIN} 3$ was the reference except in the Seattle study ${ }^{26}$ (Table III), suggesting that generally there was low misclassification between CIN 1 and CIN 2. 
The prevalence of CIN 2/3 varied widely (as would be expected given the study settings) and spanned the gamut from unscreened high-risk populations such as Shanxi Province China ${ }^{14}$ (CIN 2/3 prevalence of $\left.4.3 \%\right)$ to much lower risk populations such as the $\mathrm{UK}^{27}(\mathrm{CIN} 2 / 3$ prevalence of $1.2 \%$ ). As would be expected, the prevalence of CIN 3 was lower but exhibited a similar trend as the CIN 2/3 data with respect to the different populations.

\section{Table III \\ Cross-sectional Papanicolaou test and HPV dna test (HC2) screening studies. Data ARE For WOMEn OF ALL AGES (16 to OVER 80 Years OF AGE) UNLESS OtHeRWISE INDICATED}

\begin{tabular}{|c|c|c|c|c|c|c|c|c|c|c|c|c|c|c|}
\hline \multirow[b]{2}{*}{ Study* } & \multicolumn{2}{|c|}{ Cases of CIN } & \multirow[b]{2}{*}{ Test } & \multirow{2}{*}{$\begin{array}{l}\text { Sensitivity } \\
\%\end{array}$} & \multirow{2}{*}{$\begin{array}{l}\text { Specificity } \\
\%\end{array}$} & \multirow{2}{*}{$\begin{array}{cc}\text { PPV } & \text { NPV } \\
\% & \%\end{array}$} & \multirow[b]{2}{*}{ Study* } & \multicolumn{2}{|c|}{ Cases of CIN } & \multirow{2}{*}{ Test ${ }^{\mathrm{S}}$} & \multirow{2}{*}{$\begin{array}{l}\text { Sensitivity } \\
\%\end{array}$} & \multirow{2}{*}{$\begin{array}{c}\text { Specificity } \\
\%\end{array}$} & \multirow{2}{*}{$\begin{array}{l}\text { PPV } \\
\%\end{array}$} & \multirow{2}{*}{$\begin{array}{c}\text { NPV } \\
\%\end{array}$} \\
\hline & n & Grade & & & & & & $\mathrm{n}$ & Grade & & & & & \\
\hline \multirow[t]{4}{*}{ Reims $^{\ddagger}$} & 71 & CIN 2/3 & HPVC & 100 & $89^{\S}$ & $10^{\S} 100.0$ & Seattle ${ }^{\ominus}$ & 87 & CIN 3 & HPVC & 91 & 73 & $10^{\neq}$ & 99.6 \\
\hline & & & Pap C & 58 & 96 & $18 \quad 99.2$ & & & & Pap L & 61 & 82 & $10^{\neq}$ & 98.5 \\
\hline & & & Pap L & 84 & 95 & $15 \quad 99.8$ & & 23 & CIN 3 & $\mathrm{HPVC}^{\ddagger}$ & 86 & 83 & & $99.9^{\neq}$ \\
\hline & & & & & & & & & & Pap L ${ }^{\ddagger}$ & 50 & 86 & & $99.5^{\neq}$ \\
\hline \multirow[t]{4}{*}{ N ewfoundland\# } & 30 & $\operatorname{CIN~2/3}$ & $H P V C^{\&}$ & 68 & 91 & 99.1 & & 137 & CIN 2/3 & $\mathrm{HPVC}^{\ddagger}$ & 63 & 83 & na & na \\
\hline & & & Pap C & 40 & 92 & 1198.4 & & & & Pap L ${ }^{\ddagger}$ & 38 & 86 & na & na \\
\hline & & & Pap+HPV & 76 & 86 & 1299.3 & & & & & & & & \\
\hline & & & & & & & Morelos & 101 & $\operatorname{CIN} 2 / 3$ & HPVC & 93 & 93 & 15 & 99.9 \\
\hline \multirow[t]{6}{*}{ Guanacaste } & 138 & CIN 2/3 & HPVC & 88 & 89 & $12 \neq 99.8^{\neq}$ & & & & HPVs & 71 & 90 & 9 & 99.6 \\
\hline & & & Pap C & 78 & 94 & $18^{\neq} 99.6^{\neq}$ & & & & Pap C & 59 & 99 & 36 & 99.5 \\
\hline & $68^{\ddagger}$ & CIN 3 & $H P V c^{\ddagger}$ & 90 & 94 & $14 \quad 99.9$ & & & & Pap+HPVc & c 98 & 91 & 13 & 100 \\
\hline & & & Pap C $\ddagger$ & 78 & 94 & $13 \quad 99.7$ & & 77 & CIN 3 & $\mathrm{HPVC}^{\ddagger}$ & 95 & 94 & 17 & 99.9 \\
\hline & & & Pap+HPV & 94 & 90 & 99.9 & & & & Pap C $\ddagger$ & 58 & 99 & 37 & 99.5 \\
\hline & & & & & & & & & & $\mathrm{Pap}+\mathrm{HPVC}$ & $\begin{array}{l}c^{\ddagger} 97 \\
\end{array}$ & 93 & 16 & 100 \\
\hline \multirow[t]{5}{*}{ Cape Town } & $47^{\infty}$ & CIN 2/3 & HPVC & 84 & 85 & $17^{ø} 99.2^{ø}$ & & & & & & & & \\
\hline & & & HPVs & 66 & 83 & $13^{\circ} 98.2^{\varnothing}$ & Hannover- & 46 & CIN 2/3 & HPV & 98 & 95 & 11 & 100 \\
\hline & & & Pap C & 68 & 88 & $18^{ø} 98.4^{\varnothing}$ & Tubingen & & & Pap C & 44 & 98 & 11 & 99.7 \\
\hline & 107 & CIN 3 & Pap+HPV & 93 & 76 & 1399.6 & & & & Pap+HPV & 100 & 94 & 9 & 100 \\
\hline & & & & & & & & 37 & CIN 3 & HPVC & 97 & 95 & 9 & 100 \\
\hline \multirow[t]{2}{*}{ London } & 21 & CIN 2/3 & HPVC & 95 & 95 & $1799.9^{\neq}$ & & & & Pap C & 46 & 98 & 10 & 99.7 \\
\hline & 42 & CIN 2/3 & Pap C & 86 & 97 & $2299.8^{\neq}$ & & & & Pap+HPV & 100 & 95 & 8 & 100 \\
\hline
\end{tabular}

\begin{tabular}{|c|c|c|c|c|c|c|c|}
\hline Shanxi ${ }^{\ddagger \oslash}$ & 86 & CIN $2 / 3$ & HPVC & 95 & 85 & 23 & 99.8 \\
\hline & & & HPVs & 83 & 86 & 21 & 99.1 \\
\hline & & & Pap L & 94 & 78 & 16 & 99.7 \\
\hline & & CIN 3 & Pap+HPV & 100 & 68 & 6 & 100 \\
\hline
\end{tabular}

* For a full listing of $95 \%$ confidence intervals consult the source publications

₹ Data are for women 30 years of age or older. In the Guanacaste, Shanxi, Morelos, and Hannover-Tubingen studies, these test performance estimates were derived from a reanalysis of the raw data. In some cases such as the $\mathrm{C}$ ape Town study the continuation of the study led to many more cases than presented in the original publication. In the London study HC2 was done only on part of the specimen set whereas the Pap smear was applied to them all; hence the different numbers of $\mathrm{CIN} 2 / 3$

$\S$ W eighted average of two figures provided in Clavel et al, 2001,Table V28

\# Disease reference standard included colposcopic impression, which is known to be more subject to error than histopathology. Data were corrected for verification bias

\& Approximately two-thirds of specimens in this study were tested by $\mathrm{HC} 1$

* Some PPV and N PV values were not given in the papers. They were calculated by means of Bayes' theorem

${ }^{\infty}$ All premalignant lesions. The 9 cancers in the study were kept separate in the calculations. 0 f these, all 9 were detected by the Papanicolaou test and 8 of the 9 were detected by the HC2 test

- Calculated from Table II of W right et al $2000^{25}$

- Belinson et al $2001^{14}$ was assumed to be free of verification bias because all women had multiple cervical biopsies regardless of colposcopic impression. The estimates from Kulasingam et al $2002^{26}$ were corrected for verification bias n=number

Pap $C=$ conventional Papanicolaou test; Pap $L=$ liquid cytology

$\mathrm{HPVC}=\mathrm{HPV}$ DN A test based on clinician-collected specimens; HPVs=HPV DN A test based on self-collected specimens 
It is evident from Table III that HPV DNA testing by HC2 had a higher sensitivity (in some cases much higher) than cytology. For example, in the study from Reims France, ${ }^{28}$ HC2 HPV DNA testing detected 100\% of CIN 2/3 as compared to $58 \%$ for the conventional Papanicolaou test (a 72\% increase for HPV DNA) and $84 \%$ for the ThinPrep test (a 19\% increase for HPV DNA). Similar or greater differences between HPV DNA testing and cytology were seen in the studies from Newfoundland Canada, ${ }^{29}$ Seattle Washington, ${ }^{26}$ Morelos Mexico, ${ }^{30}$ and Hannover-Tubingen Germany, ${ }^{31}$ whereas in the other studies the improvement in HPV DNA sensitivity relative to the Papanicolaou test was somewhat less. There was not a single study in which the sensitivity of the Papanicolaou test equaled or exceeded the sensitivity of the HPV DNA test. The same observations can be made for the NPVs; the HPV DNA NPVs exceeded the Papanicolaou test NPVs in all studies.

The specificity values for HC2 HPV DNA testing were generally lower than the specificity values of the Papanicolaou test, except in the Shanxi study ${ }^{14}$ where the specificity of HPV DNA was higher than the specificity of the ThinPrep test. The PPVs of the Papanicolaou test were overall a little higher than the PPVs for HPV DNA testing. PPV of the Papanicolaou test was higher in the studies from London, ${ }^{27}$ Reims, ${ }^{28}$ Cape Town, ${ }^{25}$ and Hannover, ${ }^{31}$ and unusually high in
Morelos, ${ }^{30}$ whereas the HPV PPV was higher in the studies from Seattle, ${ }^{26}$ Newfoundland ${ }^{29}$ Guanacaste, ${ }^{32}$ and Shanxi. ${ }^{14}$

For most studies the sensitivity of the Papanicolaou test and the HC2 HPV DNA test combined were higher than either test alone. In contrast, the specificities of the combined tests were less than the specificities for either test alone but, in the majority of these combinations, the specificity decreases were small, on the order of a few percent. The PPVs of the individual or the combined tests were quite similar in some studies and decreased for the combination in others. As expected, the NPVs of HPV DNA combined with the Papanicolaou test were higher and in a few studies were $100 \%$.

Table IV shows the data for the three PCR studies. Of note, the sensitivity of the Papanicolaou test in Jena Germany was only $20 \%$ as compared to the sensitivity of the HPV DNA test, which was $89 \% .{ }^{33}$ However, in this study the Papanicolaou test had a specificity of 99\% compared to $94 \%$ for the HPV DNA PCR test. In the study from Seattle, ${ }^{26}$ the PCR test had a sensitivity of $88 \%$ for CIN 3 as compared to $61 \%$ for the ThinPrep Papanicolaou test. When restricted to women older than age 30 the PCR test detected $80 \%$ of CIN 3 as compared to $50 \%$ for the ThinPrep Papanicolaou test. In contrast to the study from Jena, ${ }^{33}$ the specificity of the HPV DNAPCR test and the ThinPrep Papanicolaou test in the Seattle study ${ }^{26}$ were similar.

Table IV

Papanicolaou test and HPV DNA screening studies by PCR for Carcinogenic HPV types

\begin{tabular}{|c|c|c|c|c|c|c|c|c|}
\hline \multirow[b]{2}{*}{ Study* } & \multirow[b]{2}{*}{ Test $^{\ddagger}$} & \multicolumn{2}{|c|}{ Cases of CIN } & \multirow{2}{*}{$\begin{array}{c}\text { Sensitivity } \\
\%\end{array}$} & \multirow{2}{*}{$\begin{array}{c}\text { Specificity } \\
\%\end{array}$} & \multirow{2}{*}{$\begin{array}{l}\text { PPV } \\
\%\end{array}$} & \multirow{2}{*}{$\begin{array}{c}\text { NPV } \\
\%\end{array}$} & \multirow[b]{2}{*}{ Odds Ratios } \\
\hline & & $n$ & Grade & & & & & \\
\hline Jena & GP5 & 114 & CIN 2/3 & 89 & 94 & 36 & 99.6 & na \\
\hline & Pap C & & & 20 & 99 & 71 & 97.5 & \\
\hline Copenhagen & GP5 & 165 & $\operatorname{CIN} 2 / 3$ & $93^{5}$ & na & na & na & 813 (same HR) \\
\hline
\end{tabular}

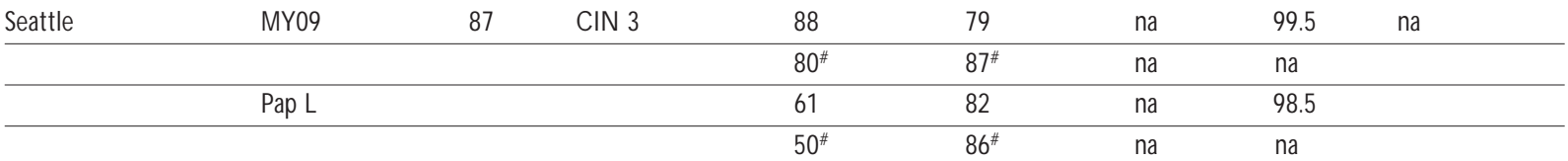

* For a full listing of $95 \%$ confidence intervals consult the source publications

₹ The types of primers used for the PCR tests were the GP5+/6+ system (GP5) or the MY09/MY11 system (MY09). Cytology tests were either the conventional Papanicolaou test (Pap C) or ThinPrep liquid cytology (Pap L)

$\S$ The Kjaer study ${ }^{16}$ was a 2-year longitudinal focus on epidemiological aspects of HPV infection in young women aged 20 to 29 years. It was not possible to determine some standard diagnostic measures from this study. 0 dds ratios are for risk of CIN 2/3 at the 2-year endpoint in women with normal cytology at baseline, according to HPV status as follows: positive for same high-risk HPV type at baseline and endpoint (same HR) or for any high-risk HPV regardless of type (any HR). The group of women HPV DN A negative at both baseline and endpoint was assigned an OR of 1.0. PCR positivity at enrollment for subsequent CIN 2/3 was given as 79\% (89/112), whereas PCR was positive at endpoint in 93\% (84/90) of CIN 2/3

\# Restricted to women 30 years of age or older as compared to women of 18 to 50 years of age, who are recorded in the rows directly above 
The PCR study from Denmark, ${ }^{16}$ was longitudinal and presented the sensitivity of the PCR test for CIN $2 / 3$ as $93 \%$. A key contribution of this study was the estimated risk of CIN 2/3 in women who were cytologically normal but HPV DNA- positive at baseline and followed for two years. The odds ratios for CIN $2 / 3$ were 692 for persistence of any high-risk HPV type and 813 for persistence of the same high-risk HPV type compared to the reference group of women who were negative for HPV DNA at both time points.

Taken as a whole, the studies indicate that the sensitivity of HPV DNA testing for CIN $2 / 3$ or CIN 3 were comparable for $\mathrm{HC} 2$ and PCR and ranged from $63 \%$ to $100 \%$ with a median of approximately $92 \%$. In comparison the sensitivity of the conventional Papanicolaou test ranged from $20 \%$ to $86 \%$ with a median value of approximately $59 \%$. The sensitivity of ThinPrep liquid cytology fell between $38 \%$ and $94 \%$.

The Portland study was a 10-year longitudinal study of HPV natural history that provided data on the risk of future CIN 3 in cytologically normal HPV-infected women. The study protocol and data have been described extensively in several publications. ${ }^{18,34-37}$ In brief, between April 1, 1989 and November 2, 1990, 23702 women were enrolled at Kaiser Permanente clinics in Portland, Oregon. Participants provided a baseline conventional Papanicolaou test and a cervicovaginal lavage specimen for HPV DNA testing. A small percentage of women were excluded for various trivial reasons and the remaining 20810 women were divided into several groups for further analysis.

Several questions related to test performance were studied, including: a) the ability of baseline HPV DNA and Papanicolaou tests to identify women diagnosed with CIN 3 during the 10 year duration of the study, b) the relative risk for future CIN 3 in the subset of women who were cytologically normal at baseline as a function of HPV DNA positivity, and c) the relative risk of CIN 3 in women with HPV DNA and Papanicolaou test negative results at baseline as compared to women who had three normal follow-up Papanicolaou tests regardless of HPV status. HPV DNA test results were not used for any aspect of the clinical management or follow-up of the women. The cohort was followed for up to 122 months by standard cytological screening, which at the time involved annual conventional Papanicolaou tests for most women. There were no important differences in follow-up characteristics of HPV DNA-positive versus HPV DNA-negative women. ${ }^{18}$ One hundred seventy-one cases of CIN 3 were detected cumulatively during the follow-up period.

Table $\mathrm{V}$ shows the relative risks of CIN 3 according to Papanicolaou test or combined test status as determi- ned by maximum likelihood estimation techniques. Figure 3 shows the secular trend for CIN 3 diagnosis during follow-up according to initial positivity by the Papanicolaou test at a cutoff of $\geq$ ASC-US, by HPV DNA alone, or by a combination of the two tests. Conceptually the groups can be viewed as risk stratifications based on the initial Papanicolaou test, initial HPV DNA, or either test positive as a combination, with the percentage of the CIN 3s that emanated from each group plotted versus time. Thus, $33 \%$ of the cumulative CIN 3 cases during the 10 years had a positive Papanicolaou test at baseline. In comparison $64 \%$ of CIN 3 patients were HPV DNA positive at baseline and $69 \%$ of CIN 3 patients were positive for either Papanicolaou or HPV DNA or both tests at baseline. Eighty-six percent $(95 \% \mathrm{CI}=80.3-92.6 \%)$ of CIN 3 patients diagnosed during the first 45 months were positive by either Papanicolaou or HPV DNA tests or both at baseline. ${ }^{18}$

Another recent longitudinal study by Bory et $a l^{38}$ is consistent with the observations of the Copenhagen study ${ }^{16}$ and the Portland study. ${ }^{18}$ It was reported that $7.7 \%(51 / 659)$ of the women initially positive for HPV DNA at baseline and 21.2\% (51/241) of women who were persistently positive for oncogenic HPV DNA types by HC2 were diagnosed with CIN 2/3 on histology within 36 months, compared to only $0.08 \%$ $(2 / 2432)$ of women initially HPV negative.

\section{Advances in HPV DNA detection}

HC2 employs RNA probes that hybridize to target DNA. Capture and detection of resulting DNA-RNA hybrids are accomplished by antibodies to DNA-RNA immobilized on the surface of a 96-well microplate. Next,

\section{Table V \\ Risk of FUtURE CIN 3 IN WOMEN \\ in the Portland study according to baseline OR FOLLOW-UP TEST STATUS*}

\begin{tabular}{|c|c|c|c|c|}
\hline Risk status & $n$ & $\begin{array}{l}\text { Women yrs } \\
\text { of follow-up }\end{array}$ & $\begin{array}{l}\text { Cases of } \\
\text { CIN } 3\end{array}$ & $\begin{array}{c}R R \\
(95 \% \mathrm{Cl})\end{array}$ \\
\hline \multicolumn{5}{|l|}{ Baseline } \\
\hline Pap ${ }^{\ddagger}$ neg & 17594 & 86210 & 48 & 0.678 \\
\hline HPV DNA neg & & & & $(0.514-0.894)$ \\
\hline \multicolumn{5}{|l|}{ Follow-up } \\
\hline 3 neg Paps & 13392 & 53566 & 44 & 1.0 \\
\hline
\end{tabular}




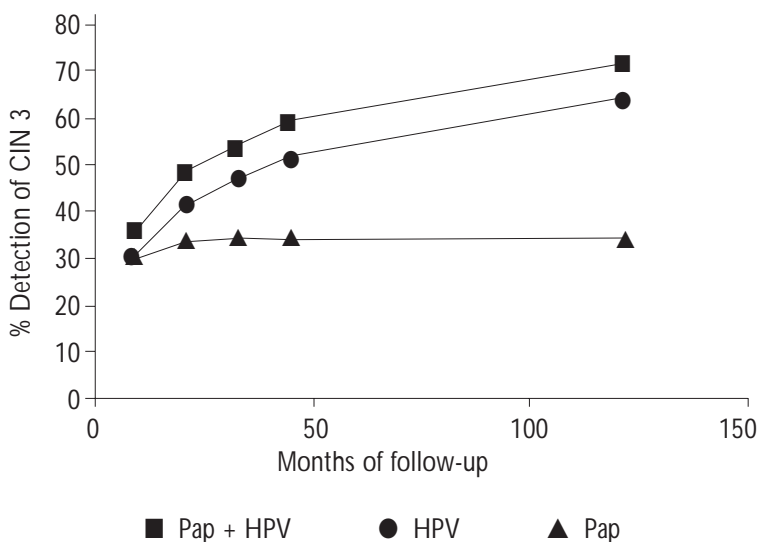

Figure 3. Baseline test detection of 171 cases of CIN 3 DIAGNOSED DURING A 10-YEAR SPAN AS A CONSEQUENCE OF ANNUAL CYTOLOGICAL SCREENING IN THE Portland study ${ }^{18}$

alkaline phosphatase-labeled anti-DNA-RNA monoclonal antibodies are reacted with the immobilized hybrids and the plate is washed. This is followed by incubation of the bound enzymes with the chemiluminescent compound CDP-Star ${ }^{\circledR}$ (Tropix PE, Bedford, Mass, USA). Dephosphorylation of the substrate produces light in a glow reaction that is measured by a luminometer. Readings are transferred directly into a software program where the results are analyzed and the number of hybrids immobilized can be quantitated.

A new format of Hybrid Capture, Hybrid Capture 3 , has been invented and developed specifically to address the need for rapid, sensitive and specific detection and discrimination of highly homologous nucleic acid targets. ${ }^{39}$ The specificity of $\mathrm{HC} 3$ is achieved by using biotinylated capture oligonucleotides to hybridize to unique sequence regions within the desired target and immobilize the target to a streptavidincoated surface. Signal is generated by RNA probes that hybridize to other regions of the target. $\mathrm{HC} 3$ provides a highly selective and sensitive method and eliminates the issue of RNA probe cross-reactivity seen with $\mathrm{HC} 2$. To a user the $\mathrm{HC} 3$ assay format is indistinguishable from the $\mathrm{HC} 2$ test. $\mathrm{HC} 3$ has been applied to the specific typing and detection of HPV and is capable of discriminating highly related HPV types such as HPV 18, 45 or HPV $16,31,35$. Both HC2 and HC3 perform similarly in the detection of the true HPV target. However, the crossreactive detection of other related HPV types has been virtually eliminated in HC3. The HPV HC3 test can be used to detect, differentiate and accurately quantify HPV types from specimens containing a mixture of HPVs at various concentrations. ${ }^{13,39}$

An automated robotic platform for Hybrid Capture called the Rapid Capture ${ }^{\mathrm{TM}}$ System (RCS) has been developed for high-volume laboratory testing. RCS is a robotic 96-well microplate processor integrating liquid and plate handling, incubations, shaking and washing directly from bar-coded primary tubes. Bulk denaturation of specimens is performed directly in the specimen collection tubes, utilizing a custom rack assembly, a multi-tube rack vortexer and a $65^{\circ} \mathrm{C}$ waterbath. Following this denaturation step, specimens are then placed into the RCS platform. Processed plates are transferred to the DML $2000^{\mathrm{TM}}$ luminometer for detection and analysis utilizing custom software. The RCS protocol provides over 3.5 hours of continuous hands-free time to the user during a run. The semiautomated application allows a single user with one RCS, employing an upgraded version of $\mathrm{HC} 2$, to test 352 specimens (4 microplates) in an 8-hour shift.

\section{Combination of HPV DNA testing and novel markers}

There has been criticism of the use of HPV testing for routine screening because most infections do not progress to cancer and thus there is the danger of excessive and costly interventions and negative psychological consequence for patients. These criticisms tend to assume that HPV tests will be conducted in an indiscriminate way by uninformed clinicians. Not only is this unlikely and not supported by recent experience in ASC-US triage but it can also be easily minimized by proper education on appropriate test usage. Nevertheless there are strong arguments for restricting use of HPV screening to women above the age at which HPV is still behaving as an STD and concentrate on those where it has become persistent and has the characteristics of a carcinogen. The best cutoff age is still under debate but is felt to be in the range of 25 to 35 years. However, even with this age stratification there is a need for additional improvement in the specificity of HPV tests. The use of novel markers is proposed as a further way to stratify HPV positive women into risk groups which can be managed by alternative algorithms. It may be possible to stratify on the basis of E6 and/or E7 expression levels although direct clinical data in support of this strategy are presently lacking. Some have suggested that novel protein markers such as p16, MCM5, EGFR, various cyclins, etc, may replace the need for HPV testing. ${ }^{40}$ However, these arguments overlook the inability of such tests to identify the full extent of the at-risk pool, namely those women who are persistently HPV infected without concurrent cytological abnormalities but who 
are at risk for high-grade disease in the coming years. We have undertaken an extensive investigation of novel protein markers to help substratify HPV-positive women. We employed immunocytochemistry to look at issues of test sensitivity and specificity of the individual and panel protein tests alone or in combination with HPV DNA testing. Preliminary data reveal that none of the markers are as sensitive for detection of HSIL as HPV DNA testing and must be used as panels to reach adequate sensitivity. However, use of such panels as stand-alone tests suffers from poor specificity (data not shown). In contrast use of a panel composed of certain cell proliferative and cell regulatory proteins on HPV- positive women appears to stratify these into groups with adequate sensitivity and specificity to be considered as a potential triage strategy. This work is still at an early stage and detailed information will be presented at a later time.

\section{Discussion}

The results of available studies provide compelling evidence for the clinical utility of HPV DNA testing as a management tool for ASC-US triage, for test of cure and as an adjunct to cervical cytology for routine screening in women older than age 30 years and perhaps in certain settings also at younger ages. The wide diversity of study locations and risk groupings is a particular strength of the combined results and indicates that the data may be generalizable to many screening settings worldwide. The cross-sectional and longitudinal data complement each other and show that women infected with oncogenic HPV constitute a higher risk group requiring more vigilant follow-up as compared to women with no evidence of HPV infection who can be regarded as being at low risk for cervical cancer.

A weakness in the screening data set relates to the lack of true assessment of all potential CIN 2/3 on the cervix. There is a concern that even combinations of screening tests may miss a large proportion of true highgrade neoplasia on the cervix (the verification bias effect). Such biases, if present, will falsely improve the appearance of HPV testing performance. However, in the study from Shanxi province in China there was a rigorous assessment of all women by colposcopy and biopsy that indicated that the HPV DNA and Papanicolaou test combined detected essentially all CIN 2/3 and cancers. In several other studies where control colposcopies were performed on the double-negative women there was virtually no CIN 2/3 detected. ${ }^{26,32,38}$ Even if verification bias were present at high levels in some or most studies it would not change the fact that HPV DNA is the more sensitive test with or without verification bias. The real impact of the bias is on the accuracy of our assessment of the absolute values of sensitivity and specificity.

HPV DNA testing using HC2 or PCR can identify almost all patients with CIN 3 or more. Adding a fluidbased cytology test to the HPV DNA test increases sensitivity by approximately $5 \%$. More importantly, the negative predictive values for the combinations were above $99 \%$ for seven studies and were $100 \%$ in 4 of the 7 . If a patient is negative for HPV DNA and has a negative Papanicolaou test, the clinician can be reassured that there is little risk of missed neoplastic disease.

Women who are HPV DNA positive but who do not have an abnormal Papanicolaou test or clinical evidence of HPV-related disease should not be viewed as having "false positive" tests. These are the women at greatest risk of developing an abnormal Papanicolaou test and cervical neoplasia prospectively, as shown by the Portland, Copenhagen, and Reims investigators. Such women can be managed by close follow-up and repeat testing.

\section{References}

1. Parkin D M, Bray F, Ferlay J, Pisani P. Estimating the world cancer burden: G lobocan 2000. Int J Cancer 20010 ct;94(2):153-156.

2. Lazcano-Ponce EC, Rascón-Pacheco RA, Lozano-Ascencio R,VelascoMondragón HE. Mortality from cervical carcinoma in Mexico: Impact of screening, 1980-1990. Acta Cytol 1996;40(3):506-512.

3. Papanicolaou GN, Traut HF.The diagnostic value of vaginal smears in carcinoma of the uterus. Am J O bstet Gynecol 1941 Aug;42(2):193-206. 4. N anda K, McC rory DC, Myers ER, Bastian LA, Hasselblad V, Hickey JD et al. Accuracy of the Papanicolaou test in screening for and follow-up of cervical cytologic abnormalities:A systematic review. Ann Intern Med 2000 May;132(10):810-819.

5. Bastian L, D atta S, H asselblad V, Hickey J, Myers E, N anda K. Evaluation of Cervical Cytology. Rockville, MD:A gency for Health Care Policy and Research; Feb 1999. Report no 5. Available from: http://

hstat.nlm.nih.gov/.Accessed July 22, 2003.

6. Fahey MT, Irwig L, Macaskill P. Meta-analysis of Pap test accuracy.Am J Epidemiol 1995 A pr;141(7):680-689.

7. Bosch FX, Lörincz A, Muñoz N, Meijer CJLM, Shah KV.The causal relation between human papillomavirus and cervical cancer.J $\mathrm{Clin}$ Pathol 2002 A pr;55(4):244-65.

8. Lörincz AT, Reid R, Jenson AB, G reenberg MD, Lancaster W, Kurman RJ. Human papillomavirus infection of the cervix: Relative risk associations of 15 common anogenital types. O bstet Gynecol 1992 Mar;79(3):328-337.

9. Bosch FX, Manos MM, Muñoz N, Sherman M, Jansen AM, Peto J et al. Prevalence of human papillomavirus in cervical cancer: A worldwide perspective.J N atl Cancer Inst 1995 Jun;87(11):796-802.

10.W alboomers JMM, Jacobs MV, Manos MM, Bosch FX, Kummer JA, Shah KV et al. Human papillomavirus is a necessary cause of invasive cervical cancer worldwide.J Pathol 1999 Jul;189(1):12-19. 11. Herrero R, Hildesheim A, Bratti C, Sherman ME, Hutchinson M, Morales I et al. Population-based study of human papillomavirus infection and cervical neoplasia in rural Costa Rica. J $\mathrm{N}$ atl Cancer Inst $2000 \mathrm{Mar} ; 92(6): 464-474$. 
12.Thomas DJ. Sexually transmitted viral infections: Epidemiology and treatment. JO GN N 2001;30(3):316-323.

13. Lörincz A, Anthony J.Advances in H PV detection by Hybrid Capture ${ }^{\circledR}$. Pap Report 2001;12(6):145-154.

14. Belinson J, Q iao YL, Pretorius R, Z hang W H , Elson P, Li L et al. Shanxi Province cervical cancer screening study:A cross-sectional comparative trial of multiple techniques to detect cervical neoplasia. G ynecol 0 ncol $2001 \mathrm{~N} \mathrm{ov} ; 83(2): 439-444$.

15. Solomon D, Schiffman M, Tarone B, for the ALTS Group. Comparison of three management strategies for patients with Atypical Squamous Cells of Undetermined Significance (ASC US): Baseline results from a randomized trial. J N atl Cancer Inst 2001 Feb;93(4):293-299.

16. Kjaer SK, van den Brule AJC, Paull G, Svare El, Sherman ME, Thomsen BL et al.Type specific persistence of high risk human papillomavirus (HPV) as indicator of high grade cervical squamous intraepithelial lesions in young women: Population based prospective follow up study. Br Med J 2002 Sep;325(7364):572-578.

17. Hall S, Lörincz A, Shah F, Sherman ME, Abbas F, Paull G et al. Human papillomavirus DNA detection in cervical specimens by $\mathrm{Hybrid}$ Capture: Correlation with cytologic and histologic diagnoses of squamous intraepithelial lesions of the cervix. Gynecol 0 ncol 1996;62:353-359.

18. Sherman ME, Lörincz AT, Scott DR, W acholder S, C astle PE, G lass AG et al. Baseline cytology, human papillomavirus testing, and risk for cervical neoplasia: A 10-year cohort analysis. J N atl C ancer Inst 2003 Jan;95(1):46-52.

19. The ASC US-LSIL Triage Study (ALTS) Group. Results of a randomized trial on the management of cytology interpretations of atypical squamous cells of undetermined significance. Am J 0 bstet Gynecol 2003 Jun;188(6):1383-1392.

20. Sherman ME, Schiffman M, C ox JT. Effects of age and human papilloma viral load on colposcopy triage: $\mathrm{D}$ ata from the randomized Atypical Squamous C ells of Undetermined Significance/Low-grade Squamous Intraepithelial Lesion Triage Study (ALTS).J N atl Cancer Inst 2002 Jan;94(2):102-107.

21. Manos MM, Kinney W K, Hurley LB, Sherman ME, Shieh-N gai J, Kurman RJ et al. Identifying women with cervical neo plasia: Using human papillomavirus DN A testing for equivocal Papanicolaou results. JAMA 1999 May;281(17):1605-1610.

22. Lonky N M, Félix JC, N aidu YM, W olde-T sadik G. Triage of atypical squamous cells of undetermined significance with $\mathrm{Hybrid} C$ apture II: Colposcopy and histologic human papillomavirus correlation. 0 bstet Gynecol 2003 Mar;101(3):481-489.

23. Paraskevaidis E, Koliopoulos G, A lamanos Y, Malamou-Mitsi V, Lolis ED, Kitchener HC. Human papillomavirus testing and the outcome of treatment for cervical intraepithelial neoplasia. 0 bstet Gynecol 2001 Nov:98(5 pt 1):833-836.

24. Chua $\mathrm{KL}$, H jerpe A. Human papillomavirus analysis as a prognostic marker following conization of the cervix uteri. Gynecol 0 ncol 1997;66:108-113

25.W right TC, Jr, D enny L, Kunn L, Pollack A, Lörincz A. H PV D N A testing of self-collected vaginal samples compared with cytologic screening to detect cervical cancer. JAMA 2000 Jan;283(1):81-86. 26. Kulasingam SL, Hughes JP, Kiviat N B, Mao C, W eiss N S, Kuypers JM et al. Evaluation of human papillomavirus testing in primary screening for cervical abnormalities: Comparison of sensitivity, specificity, and frequency of referral. JAMA 20020 ct;288(14):1749-1757.

27. Cuzick J, Beverley E, Ho L,Terry G, Sapper H, Mielzynska I et al. $\mathrm{HPV}$ testing in primary screening of older women. $\mathrm{Br} J \mathrm{C}$ ancer 1999;81(3):554-558.

28. Clavel C, Masure M, Bory JP, Putaud I, Mangeonjean C, Lorenzato F et al. Human papillomavirus testing in primary screening for the detection of high-grade cervical lesions: a study of 7932 women. $\mathrm{Br}$ J Cancer 2001;89(12):1616-1623.
29. Ratnam S, Franco EL, Ferenczy A. Human papillomavirus testing for primary screening of cervical cancer precursors. C ancer Epidemiol Biomarkers Prev 2000 Sep;9(9):945-951.

30. Salmerón J, Lazcano-Ponce E, Lörincz $A$, Hernández $M$, Hernández $P$, Leyva A et al. Comparison of H PV-based assays with Papanicolaou smears for cervical cancer screening in Morelos State, Mexico. Cancer Causes Control 2003 Aug;14(6):505-512.

31. Petry KU, Menton S, Menton M, van Loenen-Frosch F, de Carvalho Gomes H, Holz B et al. Inclusion of HPV testing in routine cervical cancer screening for women above 29 years in Germany: results for 8468 patients. Br J Cancer 2003 May;88(10):1570-1577.

32. Schiffman M, Herrero R, Hildesheim A, Sherman ME, Bratti M, W acholder $S$ et al. HPV DNA testing in cervical cancer screening: results from women in a high-risk province of C osta Rica. JAMA 2000 Jan;283(1):87-93.

33. Schneider A, H oyer H, Lotz B, Leistritz S, Kuhne-H eid R, N indl I et al. Screening for high-grade cervical intra-epithelial neoplasia and cancer by testing for high-risk HPV, routine cytology or colposcopy. Int J Cancer $2000 \mathrm{~N} \mathrm{ov} ; 89(6): 529-534$.

34. Schiffman MH, Bauer HM, Hoover RN, Glass AG, Cadell DM, Rush $B B$ et al. Epidemiologic evidence showing that human papillomavirus infection causes most cervical intraepithelial neoplasia.J $\mathrm{N}$ atl $\mathrm{C}$ ancer Inst 1993 Jun;85(12):958-964.

35. Liaw KL, G lass AG, Manos M M, G reer CE, Scott DR, Sherman M et al. Detection of human papillomavirus DNA in cytologically normal women and subsequent cervical squamous intraepithelial lesions. J $\mathrm{N}$ atl Cancer Inst 1999 Jun;91(11):954-960.

36. Castle PE, W acholder S, Lörincz AT, Scott DR, Sherman ME, G lass $A G$ et al.A prospective study of high-grade cervical neoplasia risk among human papillomavirus infected women. J N atl C ancer Inst 2002 Sep;94(18):1406-1414.

37. Lörincz AT, C astle PE, Sherman ME, Scott DR, G lass AG,W acholder $S$ et al.Viral load of human papillomavirus and risk of C IN 3 or cervical cancer. Lancet 2002 Jul;360(9328):228-229.

38. Bory JP, C ucherousset J, Lorenzato M, G abriel R, Q uereux C, Birembaut $P$ et al. Recurrent human papillomavirus infection detected with the hybrid capture II assay selects women with normal cervical smears at risk for developing high grade cervical lesions: a longitudinal study of 3091 women. Int J Cancer 2002 Dec;102(5):519-525.

39. Lörincz A, Anthony J. Hybrid C apture $\otimes_{:}: A$ system for nucleic acid detection by signal amplification technology. In:Van Dyke K,Van Dyke C, Woodfork K, Ed. Luminescence biotechnology: Instruments and applications. Boca Raton,FL: CRC Press; 2002:149-158.

40. von Knebel D oeberitz M. N ew markers for cervical dysplasia to visualise the genomic chaos created by aberrant oncogenic papillomavirus infections. Eur J Cancer $2002 \mathrm{~N}$ ov;38(17):2229-2242. 41. Lin CT, Tseng CJ, Lai CH, H sueh S, Huang HJ, Law KS. High-risk HPV DN A detection by Hybrid Capture II:An adjunctive test for mildly abnormal cytologic smears in women $\geq 50$ years of age. J Reprod Med 2000 A pr ; $45(4): 345-350$.

42. Shlay JC, D unn T, Byers T, Baron AE, D ouglas JM, Jr. Prediction of cervical intraepithelial neoplasia 2-3 using risk assessment and human papillomavirus testing in women with atypia on Papanicolaou smears. 0 bstet Gynecol 2000 Sep;96(3):410-416.

43. Zielinski GD, Snijders PJF, Rozendaal L,Voorhorst FJ, van der Linden HC, Runsink AP et al. HPV presence precedes abnormal cytology in women developing cervical cancer and signals false negative smears. $\mathrm{Br}$ J Cancer 2001 Aug;85(3):398-404.

44. Morin C, Bairati I, Bouchard C, Fortier M, Roy M, Moore L et al. Managing atypical squamous cells of undetermined significance in Papanicolaou smears. J Reprod Med 2001 Sep;46(9):799-805. 45. Pretorius RG, Peterson P, N ovak S,Azizi F, Sadeghi M, Lörincz AT. Comparison of two signal-amplification DN A tests for high-risk HPV as an aid to colposcopy.J Reprod Med $2002 \mathrm{~A} \mathrm{pr;47(4):290-298.}$ 
46. Elfgren K, Bistoletti P, Dillner L,W alboomers JMM, Meijer CJLM, Dillner J. Conization for cervical intraepithelial neoplasia is followed by disappearance of human papillomavirus deoxyribonucleic acid and a decline in serum and cervical mucus antibodies against human papillomavirus antigens. Am J 0 bstet Gynecol 1996 Mar;174(3):937-942. 47. Bollen LJM, Tjong-A-H ung SP, van der Velden J, Mol BW, Boer K, ten Kate FW J, Bleker O P, ter Schegget J. C learance of cervical human papillomavirus infection by treatment for cervical dysplasia. Sex Transm D is 1997 Sep;24(8):456-460.

48. N agai Y, Maehama T, A sato T, Kanazawa K. Persistence of human papillomavirus infection after therapeutic conization for CIN 3: is it an alarm for disease recurrence? Gynecol 0 ncol 2000;79(2):294-299. 49. Kjellberg L,W adell G, Bergman F, Isaksson M,Angstrom T, Dillner J. Regular disappearance of the human papillomavirus genome after conization of cervical dysplasia by carbon dioxide laser. Am J 0 bstet Gynecol 2000 N ov;183(5):1238-1242.
50. Lin CT, Tseng CJ, Lai CH, H sueh S, Huang KG, Huang HJ et al.Value of human papillomavirus deoxyribonucleic acid testing after conization in the prediction of residual disease in the subsequent hysterectomy specimen. Am J O bstet Gynecol 2001 A pr;184(5):940-945.

51. Jain S,T seng CJ, Horng SG, Soong YK, Pao CC. N egative predictive value of human papillomavirus test following conization of the cervix uteri. Gynecol 0 ncol 2001 Jul;82(1):177-180.

52. Elfgren K, Jacobs M, W alboomers JMM, Meijer CJLM, Dillner J. Rate of human papillomavirus clearance after treatment of cervical intraepithelial neoplasia. 0 bstet Gynecol 2002 N ov;100(5 pt 1):965-971.

53. Bodner K, Bodner-Adler B, W ierrani F, Kimberger O, D enk C,

Grunberger W. Is therapeutic conization sufficient to eliminate a highrisk HPV infection of the uterine cervix? A clinicopathological analysis. Anticancer Res 2002;22(6B):3733-3736. 